\title{
Sprawozdanie z II Międzynarodowej Konferencji \\ "The Educational and Social World of a Child. Discourses of Communication, Subjectivity and Cyborgization"
}

\section{Poznań, 26 marca 2014 roku}

26 marca 2014 roku na Wydziale Studiów Edukacyjnych Uniwersytetu im. Adama Mickiewicza w Poznaniu odbyła się II Międzynarodowa Konferencja: "The Educational and Social World of a Child. Discourses of Communication, Subjectivity and Cyborgization". Poświęcona była zagadnieniom dotyczącym świata małego dziecka, a w szczególności poruszano aspekty komunikacji, podmiotowości i cyborgizacji. Organizatorami przedsięwzięcia byli: Zakład Edukacji Elementarnej i Terapii Pedagogicznej, Zakład Psychopatologii Dziecka oraz Grupa Badawcza Cyborgizacji Edukacji Wydziału Studiów Edukacyjnych Uniwersytetu im. Adama Mickiewicza w Poznaniu, dzięki którym do Poznania przybyli przedstawiciele różnych ośrodków naukowych zarówno zagranicznych (USA, Izrael), jak i krajowych.

Uroczystego powitania zaproszonych gości oraz rozpoczęcia sesji plenarnej dokonał Dziekan Wydziału Studiów Edukacyjnych UAM - prof. zw. dr hab. Zbyszko Melosik. Następnie głos zabrała Prodziekan Wydziału Studiów Edukacyjnych UAM ds. Naukowych i Współpracy Międzynarodowej - prof. zw. dr hab. Ewa Solarczyk-Ambrozik, która podkreśliła wagę wymiany doświadczeń z różnych ośrodków naukowych oraz życzyła zebranym owocnych obrad i ciekawych dyskusji zarówno podczas sesji, jak i w kuluarach. Przewodnicząca Komitetu Organizacyjnego Konferencji - prof. UAM dr hab. Hanna KrauzeSikorska przypomniała natomiast pierwszą edycję konferencji: „The Educational and Social World of a Child. Interdisciplinary Perspective", która objęła interdyscyplinarne konteksty dotyczące przeobrażeń życia współczesnego dziecka i wyraziła nadzieję, że druga edycja również okaże się dużym sukcesem i przyczyni do powstawania kolejnych inicjatyw tego typu.

Następnie rozpoczęły się obrady, których moderatorami byli: dr Katarzyna Sadowska oraz dr Tomasz Przybyła. Pierwsza w tej części głos zabrała prof. UAM dr hab. Hanna Krauze-Sikorska, prezentując referat: „Dziecko jako osoba - dziecięca jakość życia w świecie (nie) doskonałych dorosłych”. Ujęta w nim została myśl Janusza Korczaka „Nie ma dzieci - są ludzie; ale o innej skali pojęć, 
innym zasobie doświadczenia, innych popędach, innej grze uczuć" oraz refleksji została poddana rola dorosłego w otoczeniu dziecka. Z kolei dr Andrew Bondy wraz z lic. Lori A. Frost przedstawili założenia alternatywnego pakietu interwencji rozwijających umiejętność porozumiewania się dla osób ze spektrum autyzmu i innymi zaburzeniami rozwojowymi w wystąpieniu: „The Picture Exchange Communication System (PECS)". Następnie głos zabrała prof. UAM dr hab. Agnieszka Gromkowska-Melosik, która w prezentacji „Odwrócona marginalizacja? Edukacyjne porażki chłopców" przywołała publikacje Zbyszko Melosika i postawioną przez niego tezę o istniejącym obecnie kryzysie męskości oraz odniosła ją do oczekiwań, które są wysuwane w stosunku do chłopców. Kolejny referat „Using Technology with Young Children with Autism”, autorstwa prof. dr Janice Myck-Wayne, poruszył kwestie wykorzystania Social Story $\mathrm{w}$ pracy z dziećmi z zaburzeniami autystycznymi. Celem wspomnianej metody nie jest zmiana zachowania, ale podjęcie przez osobę skuteczniejszych działań w obszarze funkcjonowania społecznego, dzięki lepszemu zrozumieniu wydarzeń i oczekiwań innych. Ostatni głos w tej części sesji plenarnej należał do prof. dr Melindy R. Pierson, która mimo że nie mogła przybyć do Poznania, przesłała swoją prelekcję: "Common Core State Standards: Education Reform in the United States" w formie video. Dzięki temu wszyscy obecni mogli zapoznać się z reformą szkolnictwa w USA.

Kolejna część konferencji dotyczyła aktywności dziecka zarówno w obszarze sztuki, jak i komunikacji. Pierwsza w tej sesji wystąpiła prof. UP dr hab. Kinga Łapot-Dzierwa z referatem: "Sztuka w świecie dziecka”. Zarysowała projekt wdrażany w przedszkolach wśród 5- i 6-latków oraz w klasach 4-6 w szkołach podstawowych, który obejmuje wychowanie estetyczne oraz rozwijanie umiejętności w zakresie ekspresji, wyrażania emocji oraz wrażliwości u dzieci. Następnie uczestnicy konferencji zapoznali się z możliwościami wykorzystania utworów lirycznych znanych autorów (np. Juliana Tuwima czy Jana Brzechwy) w edukacji przedszkolnej, dzięki wystąpieniu prof. US dr hab. Urszuli Chęcińskiej: „Sapienti sat. Język emocji poetyckich a teoria umysłu małego dziecka”. Z kolei prof. UŚ dr hab. Urszula Szuścik zaprezentowała: „Rozwój formy rysunkowej dziecka - kontekst słowa i wizualność", przyrównując rozwój rysunku i mowy. Aspekty komunikacji poruszyła prof. UAM dr hab. Kinga Kuszak w wystąpieniu: „Lęk społeczny i mutyzm wybiórczy jako zaburzenia komunikacji w okresie średniego i późnego dzieciństwa". Dokonała porównania obydwu zaburzeń oraz wypunktowania między nimi podobieństw i różnic. Natomiast prezentacja „Pytania w procesie konstruowania wiedzy uczniów” dr hab. Jolanty Bonar poruszyła kwestie roli pytań w rozwoju dzieci. Prelegentka zauważyła, że są one tłumione przez nauczycieli.

Ostatnią część obrad plenarnych rozpoczął prof. UAM dr hab. Marek Budajczak. W swoim referacie: „Między uprzedmiotowianiem a upodmiotowianiem 
dziecka - dyskursy i praktyki humanizmu" podjął refleksję nad współczesnymi nurtami i kierunkami przemian w pedagogice. Z kolei prof. UAM dr hab. Eva Zamojska w wystąpieniu: „Bestsellerowe książki dla dzieci jako (re)konstrukcje świata społecznego" zaprezentowała i porównała dwie skrajnie różne pozycje książkowe - „Zezia, Giler i Oczak” autorstwa Agnieszki Chylińskiej oraz serię „Magiczne drzewo" Andrzeja Maleszki. Wskazała istotne cechy, które świadczą o wysokiej jakości książek sytuowanych w obszarze literatury dziecięcej. Następnie dr hab. Katarzyna Segiet podzieliła się refleksją: „Dziecko podmiotem w rodzinie. Konfrontacja teorii z praktyką", omawiając kwestie podmiotowości dziecka $\mathrm{w}$ relacji z dorosłymi. Zagadnienia związane $\mathrm{z}$ edukacją medialną, środkami komunikacji młodzieży oraz byciem online/offline zostały poruszone przez prof. UAM dra hab. Jacka Pyżalskiego w prezentacji: „Edukacja medialna - gdzie jesteśmy, dokąd zmierzamy?"

Po przerwie obrady zostały wznowione w pięciu równoległych sekcjach. Pierwsza, oscylująca wokół zagadnień komunikacji oraz kompetencji dziecka w tym zakresie, była prowadzona przez dr Renatę Michalak oraz dr Grażynę Rurę. Obejmowała ona następujące referaty:

1) dr Grażyna Rura: „Edukacja (nie)rozpoczyna się w szkole? O możliwościach percypowania rzeczywistości w placówce opieki nad małym dzieckiem”;

2) dr Anna Buła: „Filozofowanie jako źródło nabywania kompetencji komunikacyjnych w edukacji wczesnoszkolnej";

3) mgr Justyna Cieślińska: „Nieznane oblicze dysleksji rozwojowej, czyli trudności wynikające z deficytów występujących w sferze komunikacyjnej oraz emocjonalno-motywacyjnej";

4) mgr Anna Wiśniewska: „Dziecko niesłyszące - czyli kto? O nieścisłościach w definiowaniu głuchoty";

5) dr Renata Michalak: „Uczenie się dziecka w perspektywie koncepcji ucieleśnionego poznania";

6) dr Ewa Żmijewska: „Elementarz narzędziem wspierania tożsamości kulturowej dziecka w młodszym wieku szkolnym”;

7) dr Dorota Radzikowska: „Książka dziecięca jako źródło poznawania świata społecznego";

8) dr Barbara Górecka-Mostowicz: „Wyjaśnianie zjawisk emocjonalnych przez dzieci w wieku przedszkolnym”;

9) mgr Małgorzata Moszyk: „Ewolucja metodyki nauczania języków obcych w kontekście dynamiki zmian rozwojowych u dzieci".

Druga sekcja oscylowała wokół zagadnień relacji dziecka z rodzicami oraz rówieśnikami, a jej koordynatorami były dr hab. Anna Jakoniuk-Diallo oraz mgr Paulina Gołaska. Ta część konferencji obejmowała następujące prezentacje:

1) dr Anna Józefowicz: „Dziecko - rodzina - rówieśnicy w najnowszej prozie polskiej dla najmłodszych w kontekście edukacyjnym"; 
2) mgr Paulina Gołaska: „Rodzicielska refleksyjność a rozwój dziecka - ujęcie dynamiczne";

3) mgr Patrycja Wesołowska: „Relacje dziecko - rodzice jako przedmiot pedagogizacji rodziców";

4) mgr Agnieszka Skowrońska-Pućka: „Dzieci w rolach rodzicielskich. Przyczyny i konsekwencje zjawiska (przed)wczesnego rodzicielstwa";

5) mgr Beata Pietkiewicz-Pareek: "How Aladdin Could Start a New Life Without a Magic Lamp? The Functioning of Orpanages for Street Children in India";

6) dr Bożena Grzeszkiewicz: „Dziecko w wieku przedszkolnym - wśród rówieśników";

7) mgr Aneta Baranowska: „Przemoc psychiczna w rodzinie a funkcjonowanie dziecka w grupie rówieśniczej";

8) mgr Izabela Kujawska: „Kontakty rówieśnicze a poziom samopoczucia dziecka sześcioletniego";

9) dr Beata A. Orłowska: „Współcześni młodzi Łemkowie - pytanie o tożsamość".

Kolejna sekcja dotyczyła osoby nauczyciela w szkole oraz przedszkolu i nosiła tytuł: „Dziecko - Otoczenie - Instytucja”. Jej moderatorami były dr Maria Paula Stasiakiewicz i dr Hanna Kubiak. Obejmowała następujące prelekcje:

1) dr Justyna Deręgowska: „Pedagog - nauczyciel w procesie wspierania dziecka doświadczającego trudnej sytuacji życiowej”;

2) Orli Noriany, M.A.: "The Gap between the Student's Assessment and the Teacher's Assessment of the Student's Work";

3) dr Małgorzata Kabat: „Edukacja, zawód, przygoda i kreatywność nauczyciela";

4) dr Barbara Kurowska: „Wartości diagnostyczne wybranych arkuszy do oceny gotowości szkolnej";

5) dr Maria Paula Stasiakiewicz: „Rysunek dziecka - nierozpoznane potencjały poznawczego rozwoju";

6) dr Anna Mikler-Chwastek: „Dziecko dwuletnie, nowe wyzwanie dla organizacji życia przedszkolnego";

7) dr Hanna Kubiak: „Zakwestionowanie aksjomatu w sytuacji niepełnosprawności dziecka - o dylematach egzystencjalnych rodziców dzieci z niepełnosprawnością";

8) dr Marzena Buchnat, dr Katarzyna Waszyńska: „Perspektywa dziecka z lekką niepełnosprawnością intelektualną w nauczaniu przedmiotu Wychowanie do życia w rodzinie";

9) dr Anna Gulczyńska, dr Aneta Wojciechowska: „Znaczenie edukacji seksualnej w rozwoju dzieci i młodzieży ze spektrum autyzmu”. 
Czwarta sekcja zatytułowana: „Dziecko - Dorosły - Kultura” dotyczyła artystycznych środków wyrazu oraz metod i technik pracy z dziećmi. Prowadziły ją prof. UAM dr hab. Kinga Kuszak oraz dr Katarzyna Sadowska. Zawierała ona następujące prezentacje:

1) dr Katarzyna Sadowska: "Zastosowanie elementów metody Dalcroze'a w procesie stymulowania rozwoju współczesnego przedszkolaka";

2) dr Małgorzata Kowalik-Olubińska: „Słuchanie dziecięcych głosów, czyli o paradygmatycznym przesunięciu w badaniach nad dzieciństwem";

3) lic. Michalina Kasprzak: "Determinants of cultural development in early childhood education"; ka";

4) mgr Joanna Szczyrba: „Muzyka jako składnik dnia powszedniego dziec-

5) mgr Marta Gliniecka: „Po co nam bohaterowie? O znaczeniu baśni filmowej i filmu fantasy w życiu dziecka";

6) dr Lucyna Maksymowicz: „Świat teatru jako edukacyjna przestrzeń dziecka";

7) mgr Joanna Ewa Konieczka: "Children of the revolution: youth and kids versus culture - the potential of participation in riots and subcultures";

8) dr Mariola Gańko-Karwowska: „Interakcje wychowawcze w świetle koncepcji działania komunikacyjnego J. Habermasa".

Sekcję poruszającą tematykę cyborgizacji, techniki i roli nowych mediów w życiu dziecka oraz szkoły prowadzili dr Michał Klichowski oraz dr Mariusz Przybyła. Podczas jej trwania przedstawiono następujące referaty:

1) dr Michał Klichowski, dr Mariusz Przybyła: „Dlaczego cyborgizacja w pedagogice?";

2) dr Mateusz Marciniak: „Aktywność medialna młodzieży a konsumowanie tożsamości";

3) mgr Tal Sagie: "THERAPEE - Behavioral Cyber Therapy for Enuresis (bedwetting)";

4) lic. Marek Witold Macionga: „Nowe media w nowej szkole”;

5) lic. Edyta Drzymała: „Nastoletni blogerzy odnoszący sukcesy w showbiznesie a tożsamość młodego pokolenia”;

6) mgr Anna Michniuk: „E-dokumentacja i e-komunikacja w szkole podstawowej w świetle opinii nauczycieli korzystających z dzienników elektronicznych";

7) mgr Dominika Przybyszewska: „Dziecko wobec uzależnienia od Internetu w rodzinie";

8) mgr Zivit Vaxberg: "Children At-Risk Treatment Cyberbullying With Psychodrama".

Po zakończeniu wszystkich paneli nastąpiło uroczyste podsumowanie konferencji przez prof. UAM dr hab. Hannę Krauze-Sikorską, która omówiła za- 
gadnienia poruszone $\mathrm{w}$ poszczególnych grupach. Podkreśliła rolę, jaką dorosły pełni w życiu dziecka. Równocześnie zaakcentowała istotność stworzenia optymalnego środowiska dla niego. Następnie serdecznie podziękowała przybyłym gościom za wygłoszone referaty oraz zaprosiła do uczestniczenia wszystkich gości w towarzyszącym konferencji seminarium naukowym "The Language of Emotions".

Niewątpliwie, konferencję można zaliczyć do udanych wydarzeń naukowych dotyczących sytuacji małego dziecka. Co istotne, zarówno podczas obrad, jak i w trakcie toczących się dyskusji poruszono wiele interesujących kwestii inspirujących uczestników do refleksji i poszukiwań teoretyczno-empirycznych.

Dominika Przybyszewska 